\title{
Vida Nikpali ELEMENTS OF DRAMA IN TEACHING ENGLISH TO YOUNG LEARNERS
}

mong the many various methods and techniques drama activities are certainly
one of the most suitable in teaching young learners. Children are very good imitators and they take drama activities as a game and playtime so that their motivation and attention is highly raised and everybody wants to join in. Their creativity and imagination can be widely used if we give them the freedom to think, to walk out of reality and the chance to choose when and how they want to join in. It allows each child to put into it something of his own personality and experience.

The teacher who gets two small groups of first graders to teach English as a foreign language in one 45-minute period five times a week is considered to be lucky. At the same time it is a great responsibility for the teacher since good results are expected, and when the teacher is given the complete freedom to choose what and how to teach, it soon becomes a real challenge. There are so many things to do and so many techniques one might wish to use. To solve the problem of what to start with and how to do it we may ask ourselves: "What do 6- and 7-year olds like to do? What are they surrounded with? What are their interests?" The answer is: they like playing, moving about and touching things, they live in families, they have friends, pets, toys... If we keep this in mind we can make English teaching and learning enjoyable both for the teacher and the children. Being first graders they learn other subjects with their class teacher in their mother tongue, in this case Croatian, and the task of the foreign language teacher is to incorporate these subjects into foreign language teaching. The subjects are: arithmetic, drawing, music, physical education and basic science. Thus the English teacher has two tasks: firstly, to teach children how to communicate and express themselves in English and secondly, to give them basic knowledge of the subjects mentioned by using English. Therefore the English teacher must cooperate with the class teacher regularly and even attend her classes. As these children are beginners most of the teaching will be through listening, speaking, doing and making. Reading and writing skills are introduced very slowly and gradually. Among the many various methods and techniques drama activities are certainly one of the most suitable in teaching young learners.

\section{Advantages of drama activities}

Everyone has the natural ability and tendency to express himself through gestures, imitation, mimic no matter where he comes from, where he was brought up, where he 
lives or what age he is. Children are very good imitators and they take drama activities as a game and playtime so that their motivation and attention is highly raised and everybody wants to join in. This is an opportunity for them to express their feelings and emotions and when these are involved they try to do their best and the results are much better. Their creativity and imagination can be widely used if we give them the freedom to think, to walk out of reality and the chance to choose when and how they want to join in. When they are asked to create a situation, they use all their abilities and feel responsible for the outcome. In drama everybody is involved. It allows each child to participate, to put into it something of his own personality and experience. In creating a story, for instance, they feel free to express themselves to the utmost, knowing that the better the idea is, the more successful it is going to be. On the other hand, in making up a story it cannot be predicted what is going to happen, so everyone has to listen carefully to be able to go on with the story. Children have the feeling that they are doing something and not just what they are told to do. For play acting proper space is needed where they can move about. Being able to move they feel free both physically and emotionally. Play acting allows children to use the language along with their whole body and senses.

\section{What to pay attention to}

\section{Age}

First graders come to school with different experience, from different social backgrounds and also with age difference. Six months, or even more, often makes a great difference in a child's maturity and readiness for school. Generally speaking, girls are more mature than boys. Some pupils are very sensitive - they need a lot of attention, some are very shy and quiet - they need to build up confidence, some talk too much or tend to walk around. At this age children's attention and concentration is rather short so the teacher should provide different activities and change them several times within one school hour of 45 minutes. However, a main topic can be present in each activity. The teacher should bear in mind all these things and let each child feel relaxed and comfortable by using his ability without being pushed. Let them have their period of listening and silence, a time for "filling" and building up confidence. They will start speaking when they are ready for it.

\section{Classroom arrangement}

Drama activities require pupils to move freely. Classrooms are always full of desks but it doesn't take long to move them aside. Let the children help - they are willing to help 
especially when they know that they are going to have fun. Rearranged classrooms provide enough space in the middle for all types of drama activities and at the same time children feel free both physically and psychologically. The teacher becomes a part of the teaching process and easily creates a friendly atmosphere.

\section{The teacher}

The teacher's role is crucial because it is he who provides challenging activities, helps children and offers them the opportunity for success. The teacher creates the atmosphere and leads the children. Although he is the most important element he must try to become one with the children and do things with them taking into consideration their wishes, their feelings and ideas and allow each child to express itself as much as he can. When a problem arises the teacher should notice it as quickly as possible. It is the teacher who must find the balance between what a pupil is expected to do and what he can do so that the pupil does not feel frustrated by having to do too much or too little. At the same time the teacher must know exactly what he wants to achieve by a certain activity. He must have a clear purpose in mind when introducing an activity and focus on that. He must also believe in the value of the activity and finally he must like doing it himself and be able to transmit a positive attitude to the children. He must be able to change the original idea if it doesn't work as planned. Once he has established the working atmosphere he should withdraw and interfere only when really necessary. The teacher's task is also to encourage shy pupils and constantly build up their confidence without pushing them. Once confidence is built it is much easier to carry on activities of any kind. The teacher should support children by praising them and giving them the chance to use all aids and clues available. Lots of repetition is a very important part of the process because children forget things rather quickly. Listening skill is at this stage the basis for other activities and therefore the teacher should remind children to listen carefully and use all the senses and the previous knowledge to express themselves.

\section{The mother tongue}

It is preferable to use the foreign language most of the time but we should always check if the pupils understand the full meaning of what they hear and what they say so that the two languages actually mingle all the time. Greetings, commands, expressing feelings or condition and other everyday situations can be preformed in the foreign language. This is what they usually understand well and pick up quickly. Explanations and discussions are more difficult to understand but we should encourage them to listen and try to understand. Listening to the same things day after day helps a lot and 
comprehension becomes better and better. Some children understand the meaning of what is said better than others - let them translate it into the mother tongue instead of you and you interfere only if they don't get it right. If you praise them for understanding, they try to become even better. It is also important for the pupils to gain the habits of using the foreign language while talking to each other like: asking for something, thanking for something, giving something to someone, expressing their feelings or condition.

\section{Parents}

In our country parents do not come to classes to observe their children and help the teacher at school. They come only to parents' meetings several times a year and to individual meetings with the teacher now and then. If we tell the parents our needs and what they could do to help their children, they will be of great help - especially if they are given the choice of things they could do. In play acting there are quite a number of things parents can do, such as: making materials for the stage, making cut-outs of drawings, baking cookies for the parties, even sewing costumes for a play. They may also lend picture books, audio and video cassettes that seem interesting and appropriate. This way parents are better informed of what their children are learning and, on the other hand, children feel that parents take part in their school life and activities.

\section{Preparatory activities}

Beginners have to be given a lot of input before they can produce their own sentences and express their thoughts. That's why we start with simpler drama activities such as: warming-up exercises with lots of movements, non-verbal and verbal exercises, brainstorming activities such as guessing games, simple role plays, mime games, imitations, word-play, simulations or short puppet-shows. Of course, there are other activities through which they gain input as, for example, by means of songs and rhymes, by watching films, cartoons, video cassettes, by listening to stories from a tape or read by the teacher.

\section{Stories}

One of the best ways of using stories is by means of drama. Sometimes it is quite difficult to find a proper story which can be adopted, adapted and exploited the way we want. This is why we have to have a good selection of stories till we come across the one that suits us. And even then we have to adapt it according to the knowledge of our children. Although we keep the story in essence we can put in the parts of speech we want to teach. There are stories and fairy tales that children already know and they 
enjoy listening to them in the foreign language because they can partly understand them. Stories that the students don't know could be used for predicting and guessing while listening. Using pictures and gestures is an important part of story telling. For smaller children the bigger picture books are advisable. When we come across a story that everybody likes and the students want to hear it again and again we can be certain that such a story is a good starting point for dramatization. Simplifying the story can be done together with the children to make them think of the best way it can be shortened and at the same time to check what they can say without much difficulty and what part they like the best. Sometimes they want to change the contents of the story or to add some other moments into it - let them do it, let them use their imagination.

Here is an example of the story that my students liked very much: it is "Duckling Swims" by Rosalinda Kightley from Animal Board Books Series, published in London in 1985. This was done after several months of learning English. My students wanted to hear this story over and over again and they spontaneously started to imitate the characters that appeared in the story. It is rather simple and only little changes had to be made. They all wanted to act a different character each time, so everybody repeated everything and by exchanging the roles they all had the chance to learn it. I myself found this story interesting for this age group and very useful for practising some important parts of speech.

\section{"Duckling swims"}

The characters in the story are:

Mother Duck that leads the little Ducklings and teaches them how to swim,

The Little Duckling that is afraid of the water and is left behind,

The Frog that advises the Little Duckling to jump into the water,

The Fish that helps the Little Duckling swim.

Here is our shortened version:

Mother Duck: Swim, my little ducklings, like me! Quack, quack! Quack, Quack!

Ducklings: I can swim! We can swim! Quack, quack! Quack, Quack!

The Little Duckling: I'm afraid of the water!

The Frog: Jump into the water, like this!

The Little Duckling: Splash! ... Help! Help!

The Fish: I'll help you swim. Climb on my back!

The Little Duckling: I like the water! I can swim! Quack, Quack!

All: I can swim! We can swim! Quack, quack! Quack, Quack!

There are quite a number of different language items and concepts they learned performing this short drama: vocabulary, the use of the modal verb "can" for ability, 
imperatives, expressing feelings, pronunciation, sentence intonation ... Basic social science is incorporated in it: animals and their life, then living in a family, having friends, helping each other ...

\section{Creating their own stories}

From time to time we can try creating their own stories with the children. They are very imaginative when they are given the opportunity to express their ideas and thoughts. Here is an example of the original story that my first graders did in the second half of the school year. Each group made up their story. They all brought their favourite toys from home. While playing with them they created imaginary situations. Although they couldn't say everything they wanted to, they tried to create different situations and often asked me to help them express themselves. Everybody joined in somehow and each of them contributed something to the story. They also helped each other when we were repeating it. As a matter of fact they were playing all the time but at the same time they were using the English language. Here is the first story:

\section{That's what friends are for}

Characters:

Bimbo, a Mouse

Kiki, a Little Chick

Piri, a Rabbit

Ana, a pretty girl and her dog

The girl in a blue dress and her dog

The Cat

Panda

A policeman a helicopter

an ambulance

a double-decker

a train

Setting: The streets and parks of London.

Bimbo, the Mouse: Let's go for a walk!

Piri, the Rabbit: Yes, let's go!

Kiki, the Little Chick: Let's go! (Kiki stays behind looking at a helicopter)

Kiki, the Little Chick: Oh, look! A helicopter! Look! A helicopter!

Wait for me! (Kiki falls down and hurts himself) - Help! Help! 
The ambulance comes with a doctor: Let's go to hospital!

(Bimbo and Piri are looking for Kiki)

A policeman: What are you doing here?

Bimbo and Piri: We are looking for our friend Kiki.

Ana, the pretty girl: Kiki is in hospital.

The Little Girl in Blue (walking her dog): I saw the ambulance.

(A double-decker comes)

All: Let's go to visit Kiki! Yes, let's go!

Bimbo: What shall we take him?

Piri: Let's buy some flowers!

All: OK. Here's the money! Buy some roses! Buy some tulips!

(The train comes): Toooo, to-tooo!

All: Let's go to hospital! Let's go to visit Kiki! It's his birthday today.

(In hospital)

Kiki: I'm happy to see you!

All: How are you, Kiki?

Kiki: I'm fine, thank you!

All: Here are some flowers for you!

Kiki: Thank you very much!

All: Happy birthday to you... (singing) How old are you? (singing)

Kiki: I'm seven years old... (singing)

All: Happy birthday, Kiki! And come home soon!

The other group brought their toys and made up a different story called Good Friends. The process of doing it was the same. The results in that kind of work are actually not so important as the engagement of pupils while creating the story. They enjoy doing it, they think, they use the second language in the simulated situations and this is the greatest value of it. Notice the place where the animals got frightened by the bus and ran into the woods full of fresh air and peace. The world of magic arouses their imagination. Here is the second story: 


\section{Good Friends}

Characters:

A Fox

A Wolf

A Rabbit

A Little Bear

A Cat

A Panda
Two Brother Bears

The Little Mouse

Two Horses

A Double-decker

Pierrot

A Little Magic House

Setting: A park near the woods.

All: We are all good friends!

The Fox: Let's play something!

The Wolf: Let's play “Catch"!

All: OK.

The Little Bear: I want to play with Donald Duck!

The Rabbit: Let's play "Catch" with them!

Panda: Can I play with you?

All: Yes, of course! Come on!

Two Horses: We like jumping!

The Cat and the Panda: Let's join the other animals!

Two Brother Bears: Can we play with you?

All: Of course. Come on! Join us!

The Little Mouse: Can I play with you?

All: Yes, of course. Come on! Join us!

A Double-decker comes: Too, to-too!

All: I'm afraid... We are afraid... Let's run to the woods! (They all run into the woods.)

All: I'm hungry... We are hungry...

Pierrot: Come with me! There's a little magic house! (leads them to the magic house)

All: Here's the food! It's good. Yum, yum!

Pierrot: I like bananas.

Horses: We like biscuits.

The Mouse: I like cheese.

The Cat: I like milk.

The Bears: We like honey.

Panda: I like chocolate biscuits. 
The Rabbit: I like carrots.

The Wolf: I like meat.

The Fox: I like hamburgers.

All: We are tired. I'm sleepy. We are sleepy. Let's go to bed. Good night. Sleep well!

(The actual performance of the two stories has been videotaped.)

\section{Holidays as the starting point for drama activities}

Holidays are special time of the year which can be very well used for drama activities. Children like holidays because they bring a change to everyday routine and they want to participate in preparations for them. They feel the special atmosphere and are emotionally prepared to join in. These are the holidays suitable for carrying out drama activities: Halloween, Thanksgiving, Christmas, St. Valentine's, Easter...

\section{Halloween}

This holiday is very suitable for getting children's imagination to work. They enjoy simulating something that excites them and brings them to the world of the unreal. Their emotions grow while they pretend to be ghosts, witches, bats, black cats, monsters, spiders... Enjoyable activities can go on while preparing for the central part of this holiday which is a short play (acting).

I have done it with my first graders and they have enormously enjoyed doing it. Preparations started about two weeks before Halloween, which is on 31 October.

\section{Preparatory activities}

- cutting a pumpkin (Jack o'lantern)

- drawings and cut-outs (ghosts, witches, bats, black cats...)

- displaying decorations

- playing games (Who am I?, guessing games, mime games)

\section{Acting "Trick or Treat"}

As Halloween is not a holiday for children in our country, I explained my pupils the custom that is held in some English speaking countries. Our children have a similar experience of disguising themselves during the time of carnival, which takes place in February. They accepted this simulated situation pretending they went "trick or treating". The acting started with the rhyme: In a dark, dark wood there is a dark, dark house... (We pulled the shades and the room was darkened.) 
Everybody moves around and imagines to be a character that appears on Halloween. Different sounds are produced as they say:

- I'm a ghost. I can fly.

- I'm a bat. I can fly, too.

- I'm a black cat. Miaow-miaow.

- I'm a witch. Wee-wee.

- I'm a monster. I can grab you.

- Let's go “Trick or treating"!

- Let's ring the bell! Ring the bell! Ting-a-ling-a-ling!

The person that opens the door says: Who are you?

All: We are ghosts. We are bats. We are black cats. We are witches. We are monsters. The person: What do you want?

All: Trick or treat! Trick or treat!

The person: Oh, I'm afraid. Here are some sweets! (simulates throwing the sweets and everybody pretends picking the sweets up from the floor)

All: Thank you! Bye, bye-bye! Let's go to another house!

I have never seen happier faces than during this acting. Excitement, emotions, feelings and joy mixed together so that they cannot hide any. The sweets that they get are special ones. And all this happens in such a short time, the acting itself lasting only about five minutes. They wanted to perform this dramatization day after day, even long after Halloween was over. Later on we preformed it in the Simple Past Tense, saying what we were and what we were doing.

Presented here are the possibilities of using Halloween as the topic for different activities where all four skills are included. With beginners it can be done in a simple way and gradually, year after year, we can have more complex projects depending on the teacher's and pupils' interests, creativity and imagination: 


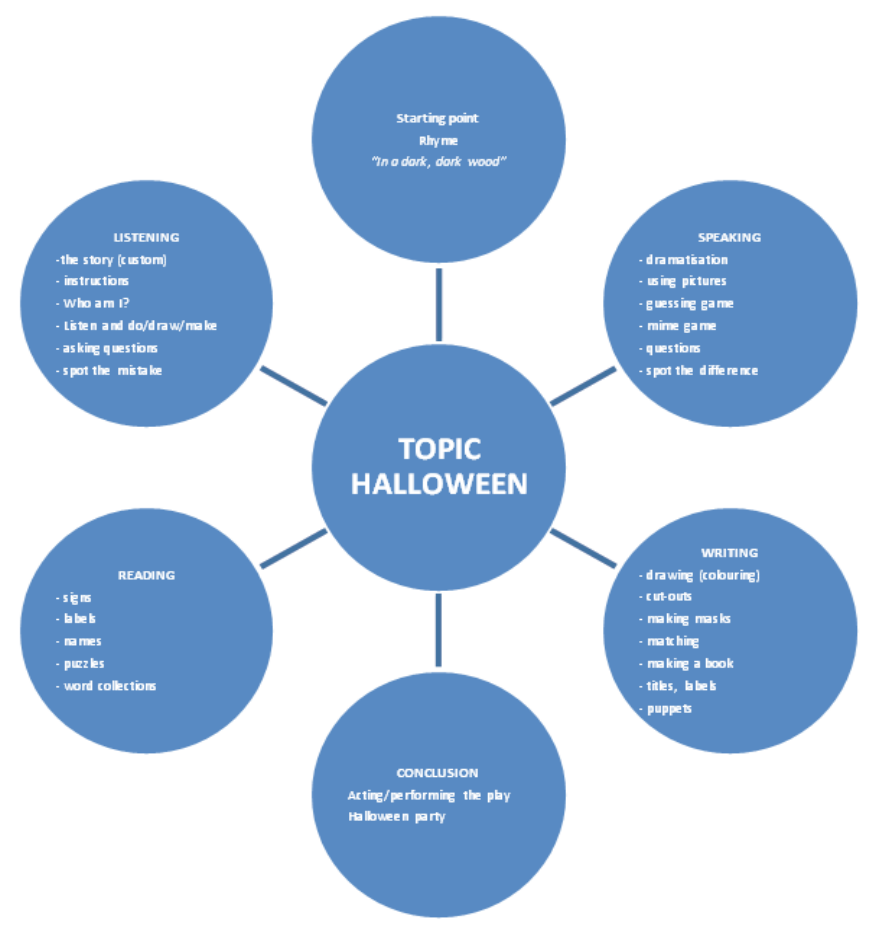

Speaking about holidays, Christmas is probably the most joyous for all people. I have done it with my pupils in a simple form of dramatic presentation where Christmas carols were included. Other activities can be a part of the Christmas project with the focus on performing a nativity play.

\section{Fairy tales}

If we decide to do a project with many activities circled around a topic with a lot of input for the children and different subjects included, we may choose one of the wellknown fairy tales such as: Cinderella, Little Red Raiding Hood, Snow White, The Sleeping Beauty, Jack and the Beanstalk, Goldilocks and the Three Bears, Three Little Pigs, The Elves and the Shoemaker and others. These and other fairy tales are suitable for drama activities but not in the way it is done in the theatres, where the actors get the text and learn it by heart. They can be used for creative drama activities, where the story actually becomes just the starting point. Most of the pupils know the content of these fairy tales and they are fond of them, which has been proved throughout years with all generations. Children read them in their own language, watch them on videocassettes. There are also cartoons based on fairy tales which children enjoy watching. Teaching younger children we have to adapt the story to the level of children's knowl- 
edge. The plot can be changed too and the characters introduced in some other way if wanted. The teacher usually prepares the things he wants to focus on, but I have noticed from my own experience that the best things come "on the spot". This depends on the situations, on the mood of the pupils, on the way the story is conducted and the ideas that come from all taking part. Such activities can go on for months with very many dramatic elements present during the work. Through such a project pupils get a lot of input and other teaching subjects are incorporated into it and not taught separately. There is always a chance to revise the vocabulary and structures they already know and use them in new situations. Spiral learning is achieved through fun, playing and joy. We can use all tenses - past, present and future. In spite of imaginative work the language that is used is real. Everybody has to make an effort to try to express his thoughts and feelings and put the words together so that they can be understood by others. Discussion with the pupils is very important. When the activity is their choice they like doing it and do not feel that they are being told to do something.

Here is an example of how the fairy tale Snow White can be exploited:

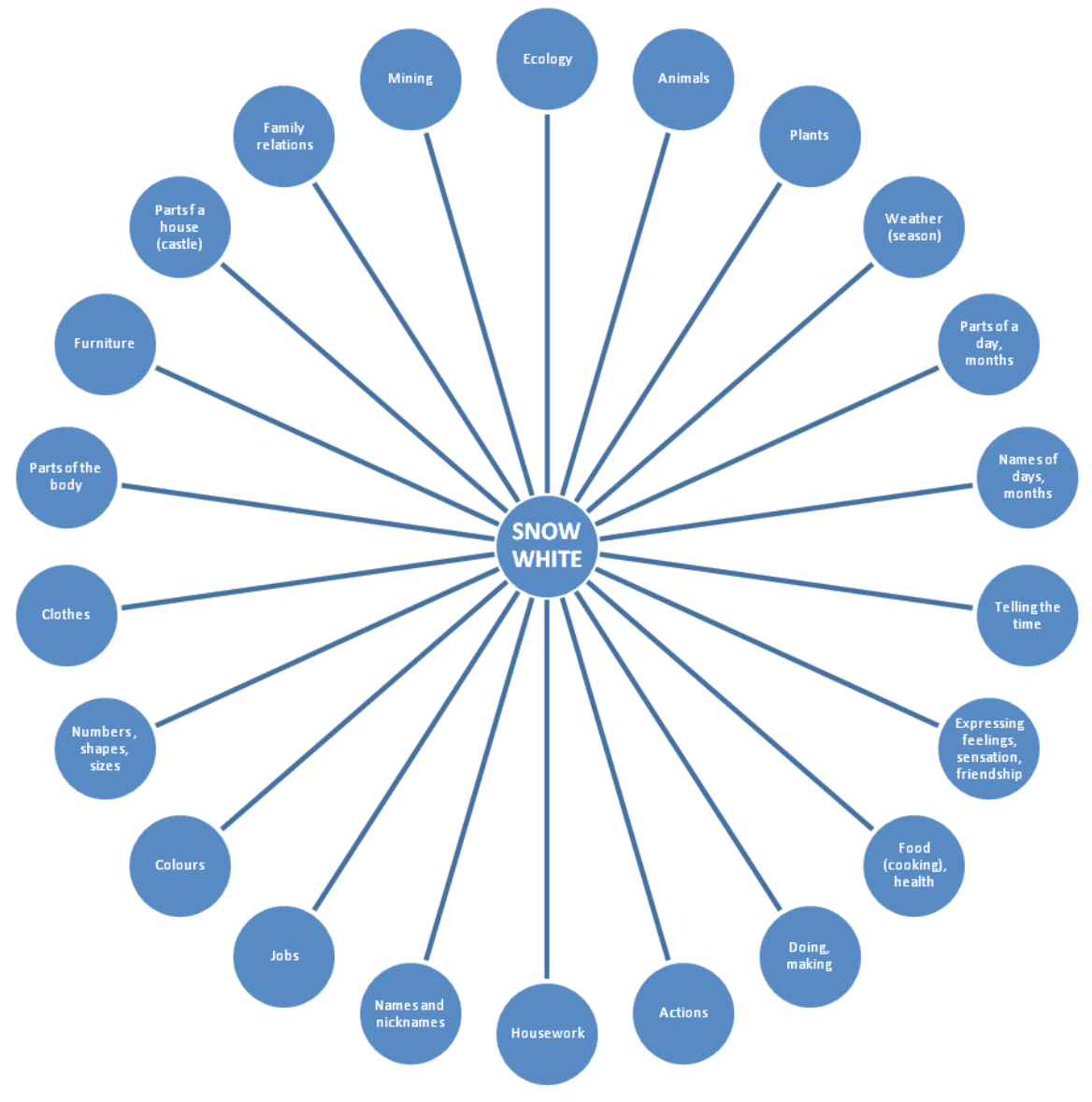


We have shown here only some possibilities of using drama in teaching a foreign language to young learners. In drama teaching anything can be taken as the starting point: any object, any animal, any rhyme or song, any story. From the starting point we build up our activities where all the teaching points are included hoping that everybody learns something from it but, what is even more important, feels comfortable and relaxed and enjoys doing it.

\section{Bibliography}

Altman, H.B. (Ed.). (1972). Individualizing the foreign language classroom. Rowley, MA: Newbury House Publishers Inc.

Broughton, G., Brumfit, Ch., Flavell, R., Hill, P. \& Pincas, A. (1978). Teaching English as a foreign language. London: Routledge \& Kegan Paul.

Dongill, J. (1987). Drama activities for language learning. London: Macmillan Publishers Ltd. Garvie, E. (1990). Story as a vehicle: Teaching English to young children. Clevedon: Multilingual Matters.

Kennedy, C, \& Jarvis, J. (Eds.) (1991). Ideas and issues in primary ELT. Nelson: The Centre for British Teachers.

Kinsella, V. (Ed.) (1978). Language teaching and linguistics: Surveys. Cambridge: Cambridge University Press.

Lee, W.R. (1965). Language-teaching games and contests. Oxford: Oxford University Press.

Littlewood, W.T. (1981). Communicative Language Teaching. Cambridge: Cambridge University Press.

Maley, A. \& Duff, A. (1982). Drama techniques in language learning. Cambridge: Cambridge University Press.

Prebeg-Vilke, M. (1991). Vaše dijete i jezik [Your child and language]. Zagreb: Školska knjiga. Shackleton, M. (1985). Double Act: ten one-act plays on five themes. London: Edward Arnold. Stanislawczyk, I.E. \& Yavener, S. (1976). Creativity in the language classroom. Rowles, MA: Newbury House Publishers Inc.

Ur, P.(1981). Discussions that work. Cambridge: Cambridge University Press. 